\title{
Effect of irrigation levels and planting methods on phenology, growth, biomass and harvest index of spring Wheat under semiarid condition
}

\author{
Khair Muhammad Kakar ${ }^{1 *}$, Amanullah ${ }^{1}$, Muhammad Saleem², and Asif \\ Iqbal $^{1}$ \\ 1. Department of Agronomy, Faculty of Crop Production Sciences, The University of Agriculture, Peshawar-25130 \\ 2. Agriculture Research System Zhob, Balochistan \\ *Corresponding author's email: agrarian786@yahoo.com
}

Citation

Khair Muhammad Kakar, Amanullah, Muhammad Saleem, and Asif Iqbal. Effect of irrigation levels and planting methods on phenology, growth, biomass and harvest index of spring Wheat under semiarid condition. Pure and Applied Biology. Vol. 4, Issue 3, 2015, pp 375-383. http://dx.doi.org/10.19045/bspab.2015.43013

\begin{tabular}{lll}
\hline \hline Received: 28/05/2015 & Revised: 22/08/2015 & Accepted: 31/08/2015 \\
\hline
\end{tabular}

Abstract

In the globally changing scenario of water crises, efficient use of water is needed. Bed planting is one of the approaches to increase water use efficiency and crop productivity. The objective of this research study was to investigate impact of irrigation levels $\left(\mathrm{I}_{2}=2\right.$ Irrigations, $\mathrm{I}_{3}=3$ Irrigations, $\mathrm{I}_{4}=4$ Irrigations, and $\mathrm{I}_{5}=5$ Irrigations $)$ and planting bed-systems $\left(\mathrm{P}_{1}=\right.$ Flat planting in rows, and $\mathrm{P}_{2}=$ Flat planting 3 rd row skip, $\mathrm{P}_{3}=$ Bed planting broadcast on beds, and $\mathrm{P}_{4}=\mathrm{Bed}$ planting 3 rows on beds) on phenological development, growth, biomass and harvest index of wheat (cv. Fakhri-e-Sarhad). The field research was carried out at the Agronomy Research Farm of The University of Agriculture Peshawar for two consecutive years during 2001-02 (year one) and 2002-03 (year two). The experiment was designed in randomized complete block with split plot arrangements. Days to maturity and plant height showed no significant response to water levels and bed systems. Days to anthesis, tillers $\mathrm{m}^{-2}$, leaf area index, biomass yield and harvest index were significantly affected by planting methods and irrigation levels. Flat sowing produced more tillers $\mathrm{m}^{-2}$ while three rows on beds produced maximum harvest index and biomass yield. The plot irrigated five times produced more tillers $\mathrm{m}^{-2}$, biomass yield and harvest index.

Keywords: Planting methods; Irrigation; Days to anthesis; Days to maturity; Plant height; Number of tillers; Leaf area index; Biomass yield; Harvest index.

\section{Introduction}

Wheat (Triticum aestivum L.) is the most important cereal crop of world. In Pakistan too, wheat is the major staple food crop for the people of Pakistan that fulfill $95 \%$ of the food requirements of the country [1]. It contributes $10.1 \%$ to the value added in agriculture and $2.2 \%$ to the gross domestic product, and was cultivated over an area of $8,693,000$ ha with the average yield of 2852 $\mathrm{kg} \mathrm{ha}^{-1}$ during 2012-2013 [2]. These figures are not satisfactory because the average 
yield of wheat in the country is lower than some of the major wheat producing countries of the world like France, Mexico, China and USA. Though Pakistan has become self-sufficient in wheat, yet we have to produce more and more wheat to cater the food need of the growing population in future and earn foreign exchange through export of quality wheat and wheat products. Water is one of the vital factors that are necessary for proper growth, balanced development and higher yield of all crops. Water deficiency affects plant growth and grain yield $[3,4,5]$ reported that wheat crop produced maximum grain yield by applying irrigation at all definable growth stages. He pointed out that irrigation is an expensive input therefore; farmer, agronomist, economist and engineer need to know the response of yield to irrigation. Water is absolute necessity for proper functioning of all the living systems on this planet. Water is the most important factor that is necessary for proper growth, balanced development and higher yield of all crops including wheat. To fulfill their obligation of providing adequate food for human beings and their livestock, the agricultural scientists and researchers must find ways to utilize all the natural resources efficiently, including water for crop production. Greater efforts are needed to increase water use efficiency in crop production due to the recent drought and the fact that fresh water is becoming scarcer and scarcer as well as costlier and costlier competition for water between agricultural and non-agricultural enterprises continuously increase and the nonagricultural enterprises can pay more for fresh water [6].

In 1999-2000, about 40\% less water was made available from the canal system of Punjab and Sindh for wheat production and in the following year water scarcity for wheat further aggravated. There are reports that bed planting can produce good yield with less water. To coup with water scarcity, the government of Pakistan recommended bed planting for wheat, though not supported by sufficient data from station research and on farm extensive testing of the newer bed planting technology for wheat production in the country. The recommendation may have been based on some work in the country, work in other countries and rapid adoption of technology in some of the countries like Mexico [7]. There is also indication that bed planting will be better for area with too much rainfall or excessive moisture. Bed planting has shown improved water distribution and efficiency, fertilizer use efficiency, reduced weed infestation, crop lodging and reduced seed rate without sacrificing yield [8].

The bed planting system facilitates mechanical cultivation as an alternative method of weed control during the crop growing season. It also provides an opportunity for hand weeding; an economical option because of the easy field entry resulting from crop row orientation on the beds, and irrigation water management is more efficient, with less labor required with the use of furrows than with conventional flood irrigation $[9,10]$. Under the flat planting method, crop production and fertilizer use efficiency have stagnated or decreased. In addition to these problems, the nitrogen use efficiency (NUE) for wheat cultivation is only about $30 \%$, but with best management practices it can be raised to higher levels [11, 12].

However, mere shifting to a new system of planting with not enough research on other aspects of wheat production technology may not be advisable and may not increase wheat productivity under limited water availability because bed planting and conventional planting may have significant interaction with other components of the wheat 
production technology like nitrogen and variety. Nitrogen is the main essential element which is usually deficient in the soil and has to be applied to the soil which involved cost. Therefore, it is important to find out the optimum amount of $\mathrm{N}$ for bed planting of wheat. The bed planting and conventional planting may also interact with varieties as research from east Punjab have shown [7] and thus suitable variety that produce high yield under bed planting should be found through research under own conditions. The important aspect of water saving or improve water use efficiency with shift from conventional to bed planting must be well documented through research under our own conditions. Hence, data from a well-planned experiment on effect of irrigation levels under conventional and bed system of planting is required to quantify the effect of irrigation under the bed system of planting for wheat [13].

Bed planting offers many advantages in irrigated wheat production systems and we are just beginning to determine how useful wheat bed planting may be for rainfed areas. It is evident from the results that it can play an important role in environments characterized by prolonged water logging as a result of excessive rainfall. The role bed planting may play in areas where water is a limiting factor; hence the application and adaptation of permanent beds increase its feasibility. The great benefit of wheat production resulting from bed planting is the tremendously enhanced field access, which facilitates controlling weeds and other pests, handling nutrients, reducing tillage, and managing crop residues [10].

The important aspects of research needed to make a realistic decision to change from conventional to bed system of planting for sustainable higher yield of wheat under water shortage, have provided the basic idea for this research. This study was initiated to study the impact of planting methods and irrigation levels with an aim of improving wheat productivity with less water [14].

\section{Material and Methods}

The experiment entitled "effect of Irrigation Levels $\left(\mathrm{I}_{2}=2\right.$-Irrigations, $\mathrm{I}_{3}=3$-Irrigations, $\mathrm{I}_{4}=4$-Irrigations, and $\mathrm{I}_{5}=5$-Irrigations) under Bed-System of Planting $\left(\mathrm{P}_{1}=\right.$ Flat planting in rows, $\mathrm{P}_{2}=$ Flat planting 3 rd row skip, P3 = Bed planting broadcast on beds, and $\mathrm{P}_{4}=$ Bed planting 3 rows on beds) on Wheat" was conducted at the Agronomy Research Farm of The University of Agriculture Peshawar, for 2-years during 2001-02 and 2002-03. The experiment was performed in randomized complete block design having four replications. Main plot size of $14.4 \mathrm{~m} \times 27 \mathrm{~m}$ and sub-plot size 3.6 $\mathrm{m}$ x $6 \mathrm{~m}$ was used. Planting system \& irrigation levels $(4 \times 4=16)$ combinations were allotted to main-plots, while irrigation levels were allotted to sub-plot. Detailed of the treatments are "Planting methods: $\mathrm{P}_{1}=$ (Rows $30 \mathrm{~cm}$ apart in case of flat planting), $\mathrm{P}_{2}=(30 \mathrm{~cm}$ apart rows 3rd row skip, in case of flat planting), $\mathrm{P}_{3}=(3$-beds in case of bedplanting. $90 \mathrm{~cm}$ bed and broad cast on beds), $\mathrm{P}_{4}=$ (3-beds in case of bed-planting. $90 \mathrm{~cm}$ bed and 3 rows on beds)". "Irrigation schedules: $\mathrm{I}_{2}=3$ rd week after emergence + irrigation at Boot stage, $\mathrm{I}_{3}=3$ rd week after emergence + irrigation at boot stage + Milk stage, I4 $=3$ rd week after emergence + Tillering + Irrigation at anthesis + Milk stage, I5 $=3$ rd week after emergence + irrigation at jointing + Boot + Anthesis + Milk." The experimental plot was irrigated and at proper moisture level the land was thoroughly prepared. The recommended dose of NPK (120:90:60 kg ha-1) were applied as basal dose. Full dose of $\mathrm{P}$ and $\mathrm{K}$ and half of $\mathrm{N}$ dose were applied and mixed with the soil during seed bed preparation. The remaining half of the $\mathrm{N}$-dose was applied with first irrigation. Sowing was 
done in 2nd week of November using variety "Fakhri-e-Sarhad". Data were recorded on the following parameters (Days to anthesis, days to maturity, plant height (cm), number of tillers m-2, leaf area index, biomass yield $\left(\mathrm{kg} \mathrm{ha}^{-1}\right)$, harvest index $(\%)$. Data on days to anthesis was recorded from date on which 75 percent of the spikes reach anthesis stage was recorded from each experimental unit. Days to anthesis were calculated as difference between date of anthesis and date of sowing. Date of physiological maturity was recorded for each experimental unit. Complete loss of green colour from glumes and peduncle was used as criteria for physiological maturity. Days to maturity were calculated as difference between the date of physiological maturity and date of sowing. Plant height (cm) was measured at physiological maturity. Seven representative tillers were selected in each experimental unit and the height measured from ground level to the tip of the spike. Two representative rows were selected in each experimental unit. Numbers of tillers were counted in the selected rows. Tillers $\mathrm{m}^{-2}$ was calculated from the number of productive tillers counted and the area sampled. Leaf area index was calculated according to the following formula:

Leaf area per tiller sq.cm x No. of tillers $\mathrm{m}^{-2} \div 10000=$ LAI

Six central rows were harvested; the material was air-dried and weighed to record biomass yield and then biomass yield $\mathrm{kg} \mathrm{ha}^{-1}$ was calculated. Harvest index was calculated by using the formula:

Harvest index $=\frac{\text { Economic yield }}{\text { Biolog ical yield }} \times 100$

Data ware statistically analyzed according to randomized complete block design with split plot arrangement and means were compared using LSD test $(\mathrm{P} \leq 0.05)$.

\section{Results and Discussion}

\section{Phenology}

Days to anthesis of wheat as affected by planting methods and irrigation levels are shown in Table 1. Analysis of the individual year data depicted that planting methods had significant effect on anthesis while irrigation levels failed to show any significant effect on number of days to anthesis. Similarly combined analysis of the two years data caused no significant effect due to planting methods and irrigation levels as shown in Table 1. It is evident from the results that flat sowing in rows reached anthesis stage earlier (126.78 days) than other nearest planting like bed sowing 3 rows which took 132.41 days. The planned comparison also showed that differences between solid sowing and skip sowing and differences between broadcast on beds and line sowing on beds were significant which may be due to differences in the environment provided to seed and rate of development of wheat under the four different planting methods. According to [15], irrigation levels had no effect on days to anthesis.

Number of days to maturity of wheat as affected by planting methods and irrigation levels are reported in Table 1. Analysis of the one year individual data on days to maturity showed that planting methods and irrigation levels was not significant. Similar was the case of the combined analysis of two years data which failed to bring about significant variation due to planting methods and irrigation levels on days to maturity.

\section{Growth}

Data regarding plant height of wheat as affected by planting methods and irrigation levels are reported in Table 1. Perusal of the each year and combined of two years analysis of data on plant height showed that planting methods and irrigation levels had no significant effect on plant height. It is evident from the results that the increase in number of irrigation did not produce taller 
plants even if provided with two irrigations or four irrigations. In 2002-03 flat planting in rows produced shorter $(91.19 \mathrm{~cm})$ plants as compared to other three planting methods. While in the first year 2001-02 flat planting 3rd row skip, produced shorter $(84.25 \mathrm{~cm})$ plants. Similar results were reported by [16] who suggested that plant height was favorably affected by increased irrigation.

Data referring to number of tiller $\mathrm{m}^{-2}$ of wheat as affected by planting methods and irrigation levels are presented in Table 1. Statistical analysis of each year individual as well as two years combined data revealed that planting methods and irrigation levels had significant effect on number of tillers $\mathrm{m}^{-}$ 1. The number of tillers $\mathrm{m}^{-2}$ increased with increase in number of irrigation at the rate of about 13 tillers $\mathrm{m}^{-2}$ per irrigation as shown in Table 1. It is crystal clear that flat sowing in rows produced the highest (452.09) number of tillers followed by bed sowing 3rows (410.91) while the lowest number (298.91) was produced by bed sowing broadcast. The results are in contrast with [13] who concluded that raised bed planting produced the minimum number of tillers as compared to flat planting system. The irrigation results are however, in conformity with [17, 16] who obtained maximum tillers by increasing irrigation levels. The trend in the response to the irrigation treatment suggests that the crop was exposed to very light stress that only slightly impaired proper vegetative growth and development. Similar result of minor decreases in growth attributes following imposition of various irrigation regimes were obtained by $[18,19]$. One of the reasons could be fewer emergences in bed sowing broadcast and greater emergence in flat sowing in rows. The planned comparison between the methods of planting indicated that line sown wheat on beds produced significantly higher number of tillers $\mathrm{m}^{-2}$ than that planted by broadcast on beds. It may be due to the moisture availability in the root zone under bed and flat planting systems. According to [15], irrigation throughout the growth stages increased the number of tillers by $20.58 \%$ compared to no irrigation. Similarly $[20,21$, 22] reported a decline in number of tillers plant $^{-1}$ under water deficit condition in different crops.

Leaf area index of wheat as affected by planting methods and irrigation levels are reported in Table 1. Analysis of each individual year and combined two years data on leaf area index indicated that planting methods and irrigation levels had significant effect on leaf area index. Leaf area index is a measure of leafiness expressed per unit ground area. Flat planting in rows produced maximum (5.35) leaf area index closely followed by bed planting 3-rows (5.30), while bed planting broadcast produced the lowest (3.42) leaf area index. The planned comparison showed that on the average flat planting produced higher leaf area index than bed planting which is mainly due to the lowest leaf area index of broadcast sowing on beds. Solid sowing had significantly greater leaf area index than skip row sowing. As leaf area index depend upon tillers per square meter and leaf area tiller ${ }^{-1}$, the differences in leaf area of the crop under different planting methods may be due to interaction of internal genetic factors with environmental factor especially light and water status of the soil. The difference could be due to better light penetration in bed planting 3-rows and greater number of tillers in flat planting in rows as compared to the other two methods of planting i.e. flat skip row and broadcast on beds. The increase in leaf area index with irrigation is due to increase in tillers meter- 2 and leaf area tiller ${ }^{-}$ 1 . Both of these characters as well as leaf area index may have been increased due to 
increased water availability that affect cell division and cell enlargement. The lowest increase in leaf area index with increase in irrigation was noted in bed planting broadcast. The reason could be the differences in water status of the root zones under the different planting methods. According to $[18,19]$, increasing irrigation regime enhanced growth attributes such as leaf area index in wheat.

\section{Biomass yield and harvest index}

Biomass yield is a product of number of tillers $\mathrm{m}^{-2}$ and tillers weight including spike weight and grain weight. The differences in biomass yield of the different planting methods could be variation in tillers $\mathrm{m}^{-2}$ and tiller weight. Both of these have been differentially affected by the soil and environmental conditions imposed by different planting methods. Data relating to biomass yield of wheat as affected by planting methods and irrigation levels are presented in Table 1. Statistical analysis of the individual year and combined two years data on biomass yield indicated that planting methods and irrigation levels had significant effect on biomass yield. The planting method flat planting in rows produced the highest biomass yield of $\left(14605 \mathrm{~kg} \mathrm{ha}^{-1}\right)$ followed by bed planting 3-rows $(13524 \mathrm{~kg}$ $\mathrm{ha}^{-1}$ ) biomass yield and further followed by the lowest $\left(12150 \mathrm{~kg} \mathrm{ha}^{-1}\right)$ biomass yield under bed planting broadcast. Biomass yield increased from $12833 \mathrm{~kg}$ ha-1 in plots irrigated twice to $13764 \mathrm{~kg}$ ha-1 in plots irrigated five times. These results are in conformity with [23]. The difference could be variation in light, light interception and water use efficiency for the production of total biomass.

Data regarding harvest index of wheat as affected by planting methods and irrigation levels are presented in Table 1. Analysis of the individual year data of harvest index indicated that planting methods and irrigation levels had significant effect on harvest index of wheat. Similarly the combined analysis of two years data of harvest index also revealed that planting methods and irrigation levels had significantly affected the harvest index. Planting methods bed planting 3-rows on beds showed the highest harvest index of $39.57 \%$ but flat planting in rows and flat planting 3rd row skip indicated slightly parallel harvest index i.e. $34.30 \%$ and $35.38 \%$ respectively, while, planting method bed planting broadcast attained the lowest harvest index of $28.80 \%$ as shown in Table 1. Harvest index increased from $31.60 \%$ in plots that received two irrigations up to $35.86 \%$ in plots which received five irrigations. The most plausible explanation of these results could be the timely application of irrigation water and at the accurate stage of the crop while the better light penetration could be another valid reason for such variations. According to [15], irrigation at all growth stages of crop plant increased harvest index over no irrigation treatment in both cultivars by $16.71 \%$. These results are similar to those of [24] who found reduced values of harvest index under water stress conditions. Also, [25] observed that controlled soil water contents can improve the grain yield and harvest index. 
Table 1. Days to anthesis, days to maturity, plant height $(\mathrm{cm})$, number of tiller $\mathrm{m}^{-2}$, leaf area index, biomass yield $\left(\mathrm{kg} \mathrm{ha}^{-1}\right)$ and harvest index $(\%)$ of wheat as affected by planting methods and irrigation levels.

\begin{tabular}{lccccccc}
\hline Treatments & $\begin{array}{c}\text { Days } \\
\text { to } \\
\text { anthesis }\end{array}$ & $\begin{array}{c}\text { Days } \\
\text { to } \\
\text { maturity }\end{array}$ & $\begin{array}{c}\text { Plant } \\
\text { height } \\
(\mathrm{cm})\end{array}$ & $\begin{array}{c}\text { Number } \\
\text { of } \\
\text { Tillers m }\end{array}$ & $\begin{array}{c}\text { Leaf } \\
\text { Area } \\
\text { index }\end{array}$ & $\begin{array}{c}\text { Biological } \\
\text { yield } \\
\left(\mathrm{kg} \mathrm{ha}^{-1}\right)\end{array}$ & $\begin{array}{c}\text { Harvest } \\
\text { index } \\
(\%)\end{array}$ \\
\hline $\mathbf{P}_{1}$ & 126.7 & 159.7 & 88.22 & 452.09 & 5.35 & 14604 & 34.30 \\
$\mathbf{P}_{\mathbf{2}}$ & 131.5 & 159.5 & 88.41 & 393.88 & 4.82 & 12857 & 35.38 \\
$\mathbf{P}_{3}$ & 128.0 & 159.1 & 88.72 & 298.91 & 3.42 & 12150 & 28.80 \\
$\mathbf{P}_{4}$ & 132.4 & 160.0 & 89.00 & 410.91 & 5.30 & 13524 & 39.57 \\
\hline Significance & $*$ & $\mathrm{~ns}$ & $\mathrm{~ns}$ & $* * *$ & $* * *$ & $* *$ & $*$ \\
\hline $\mathbf{I} 2$ & 130.1 & 159.2 & 88.03 & 367.47 & 3.81 & 12833 & 31.60 \\
$\mathbf{I} 3$ & 128.4 & 159.7 & 88.28 & 385.81 & 4.16 & 13091 & 34.23 \\
$\mathbf{I} 4$ & 129.4 & 160.0 & 89.06 & 393.53 & 5.04 & 13448 & 36.36 \\
$\mathbf{I 5}$ & 130.7 & 159.4 & 88.97 & 408.97 & 5.89 & 13764 & 35.86 \\
\hline LSD & $\mathrm{ns}$ & $\mathrm{ns}$ & $\mathrm{ns}$ & $*$ & $* * *$ & $\mathrm{~ns}$ & $*$ \\
\hline $\mathbf{2 0 0 1 - 0 2}$ & 129.9 & 159.2 & 85.31 & 386.91 & 4.82 & 13764 & 33.94 \\
$\mathbf{2 0 0 2 - 0 3}$ & 129.4 & 160.0 & 91.86 & 390.98 & 4.63 & 13378 & 35.08 \\
\hline Significance & $\mathrm{ns}$ & $\mathrm{ns}$ & $* * *$ & $\mathrm{~ns}$ & $*$ & $\mathrm{~ns}$ & $\mathrm{~ns}$ \\
\hline
\end{tabular}

\section{Planned means comparison}

Flat vs. Beds planting

$* * * \quad * * *$

$*$

ns

Solid sowing vs. Skip row

$*$

ns ns

$* * *$

$* *$

$* *$

ns

Broadcast vs Lines sowing

* ns $\quad \mathrm{ns}$

$* * * \quad * * *$

$*$

$* *$

ns $=$ non-significant, and $* * *$ and $* * *$ stands for significant at 5, 1 and $0.1 \%$ level of probability, respectively.

$\mathrm{P}_{1}=30 \mathrm{~cm}$ apart rows on flats

$\mathrm{P}_{2}=30 \mathrm{~cm}$ apart rows on flats and $3^{\text {rd }}$ row skip

$\mathrm{P}_{3}=$ Broadcast on beds

$\mathrm{P}_{4}=$ Line sowing on beds

$\mathrm{I}_{2}=$ Two irrigations $\left(3^{\text {rd }}\right.$ week after emergence + boot $)$

$\mathrm{I}_{3}=$ Three irrigations $\left(3^{\text {rd }}\right.$ week after emergence + boot + milk $)$

$\mathrm{I}_{4}=$ Four irrigations $\left(3^{\text {rd }}\right.$ week after emergence + tillering + anthesis + milk stage $)$

$\mathrm{I}_{5}=$ Five irrigations $\left(3^{\text {rd }}\right.$ week after emergence + jointing + boot + anthesis + milk $)$ 


\section{Conclusion}

We concluded from the study that plots under bed planting system had better growth and produced higher yield and yield components than flat planting. Bed planting also facilitates controlling weeds and other pests, handling nutrients, reducing tillage and managing crop residues. We also found that irrigation water requirements can be reduced up to $35 \%$ compared to conventional planting or sowing with flood irrigation. Increase in number of irrigation upto irrigated five times improved growth, yield and yield components of wheat in the study area.

\section{References}

1. Malik MA, Irfan M, Ahmed ZI, \& Zahoor F (2006). Residual effect of summer grain legumes on yield and yield components of Wheat. Pak J Agric Eng Vet Science 22: 9-11.

2. Ministry of Food, Agriculture and Livestock, Federal Bureau of Statistics, Government of Pakistan, Economic Survey of Pakistan 2012-13, 2013.

3. Hussain A, Chaudhry MR, Wajad A, \& Goheer AR (2004). Influence of water stress on growth, yield and radiation use efficiency of various wheat cultivars. Int J Agric Biol 6: 1074 -1079.

4. Wajid A, Hussain A, Ahmed A, Rafiq M, Goheer AR \& Ibrahim M (2004). Effect of sowing date and plant density on growth, light interception and yield of wheat under semiarid condition. Int J Agric Biol 6: 11191123.

5. Wajid A, Hussain A, Maqsood M, Ahmad A \& Awais M (2002). Influence of sowing date and irrigation levels on growth and grain yield of wheat. $P a k$ J Agric Sci 39(1): 22-24.
6. Khatri RS, Goel AC \& Malik RK (2001). Water use and application efficiencies in bed and flat sowing of wheat in rice-wheat system under different irrigation levels. Crop Research Hisar 21(1): 20-23.

7. Hobbs PR \& Giri GS (1998). Reduced and zero tillage options for establishment of wheat after rice in south Asia. In H.J. Braun, F. Altay, W.E. Kronstad, S.P.S. Beniwal and A McNab (eds). Wheat; prospects for Global Improvement. PP. 455-65. Kluwer Academic Publishers, Netherland.

8. Hobbs PR, Sing Y, Giri SG, Lauren JG, \& Dusbury JM (2000). Direct seeding and reduced tillage options in the rice-wheat systems of the Indo-Gagnetic plants of South Asia. Paper presented at IRRI workshop, Bankok, Thailand, 25-28.

9. Fischer RA, Sayre K \& Monasterio IO (2005). The effect of raised bed planting on irrigated wheat yield as influenced by variety and row spacing, Australian Centre for International Agriculture Research Proceeding 121, of a workshop on "Evaluation and performance of permanent raised bed cropping systems in Asia, Australia and Mexico. Grifith, NSW, Australia.

10. Sayre KD \& OHM Ramos (1997). Applications of raised-bed planting systems to wheat, CIMMYT Series: CIMMYT Wheat Program Special Report, 31.

11. Ortega LA, Sayre KD \& Francis CA (2000). Wheat nitrogen use efficiency in a bed planting system in northwest Mexico, Agron J 92: 303-308.

12. Raun, WR, Solie JB, Johnson GV, Stone ML, Mullen RW, Freeman KW, 
Thomason WE, and Lukina EV. (2002). Improving nitrogen use efficiency in cereal grain production with optical sensing and variable rate application, Agron J 94: 815-820.

13. Mascagni HJ, Keisling TC, Sabbe WE, May M, Oliver LR \& Vories ED (1995). Wheat production on raised beds on clayey and silt loam soils. Commun. Soil Sci Plant Analysis 26(3 4): 503513.

14. Melhuish FM, Humphreys E, Muirhead WA \& White RLJ (1991). Flood irrigation of wheat on a transitional red-brown earth. I. Effect of duration of ponding on soil water, plant growth, yield and $\mathrm{N}$ uptake. Australian J Agric Res 42(7): 10231035.

15. Ngwako S \& Mashiqa PK (2013). The effect of irrigation on the growth and yield of winter wheat cultivars. Intl $J$ Agric Crop Sci 5 (9): 976-982.

16. Singh S \& Bhan VM (1998). Response of wheat and associated weeds to irrigation regime, nitrogen and 2,4D. Indian J Agro 43(4): 662-667.

17. Niaz, A, Saqib R, Ramzan M \& Nauman Q (1996). Impact of management practices in reuse of subsurface drainage water. Proceedings of $6^{\text {th }}$ drainage workshop on drainage and the environment, Ljubljana, Slovenia.

18. Falaki AM (1994). Response of dwarf wheat varieties to different water Stress levels dates of sowing and nitrogen fertilization; PhD Thesis; Ahmadu Bello University; Zaria, Nigeria.
19. Kumar V \& Yayock JY (1980). Growth stages and productivity of wheat at two dates of planting at Samaru; A paper presented at the $7_{\text {th }}$ National irrigation seminar held at Baguada Lake Hotel Kano.

20. Seghatoleslami, MJ, M. Kafi, and E. Majidi (2008). Effect of deficit irrigation on yield, WUE and some morphological and phonological traits of three millet species. Pak $J$ Bot 40(4): 1555-1560.

21. Tuong TP, Bouman BAM \& Mortimer M (2005). More rice, less water integrated approaches for increasing water productivity in irrigated rice based systems in Asia. Plant Prod Sci 8(3): 229-239.

22. Kabir, N., AR. Khan, MA. Islam, and MR. Haque (2009). Effect of seed rate and irrigation level on the performance of winter wheat $\mathrm{cv}$. Gourab. J Bangladesh Agri Uni 7(1): 47-52.

23. Sharma DK \& Sharma DR (1999). Sustainable use of poor quality water with proper scheduling of irrigation and nitrogen levels for a rice crop. Water Sci and Tech 40(2): 111-114.

24. Van den Boogaard R, Veneklaas EJ, Peacock JM \& Lambers H (1996). Yield and water use of wheat in a Mediterranean environment: cultivar differences and sowing density effects. Plant Soil 181: 251-262.

25. Kang S, Zhang L, Liang Y, Hu X, Cai H, \& Gu B (2002). Effects of limited irrigation on yield and water use efficiency of winter wheat in the Loess Plateau of China. Agric Water Management 55(3): 203-216. 